\title{
Wioleta Tomczyńska
}

\section{Digital exclusion - definicje, przyczyny, przeciwdziałanie}

\section{Wprowadzenie}

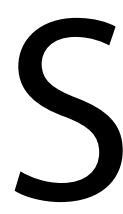

zybki rozwój i ekspansja technologii o charakterze informatyczno-komunikacyjnym są obecnie zauważalne w każdej dziedzinie życia. Zmienił się zarówno sposób pracy, nauki, jak również spędzania czasu wolnego. Rewolucja zwana informacyjną, elektroniczną bądź cyfrową (Aftański, 2011; Muszyński, 2010) doprowadziła do przekształcenia się tradycyjnego społeczeństwa industrialnego w nowy wymiar społeczeństwa globalnego, tj. społeczeństwo informacyjne'. Najważniejsze stały się trzy aspekty: informacja, wiedza i technologia. Niedobór któregoś ze składników owej triady świadczy o opóźnieniu cywilizacyjnym danego społeczeństwa (Aftański, 2011). Niestety, poza nowymi możliwościami

\footnotetext{
${ }^{1}$ Terminem „społeczeństwo informacyjne” określa się społeczeństwo, którego podstawowym środkiem bogacenia się stopniowo przestaje być tradycyjny przemysł, a zastępuje go sfera usług, w związku z czym liczba osób trudniących się przetwarzaniem i zarządzaniem informacjami staje się większa niż liczba pracowników fizycznych. Wytwarzanie, magazynowanie i przetwarzanie różnego rodzaju danych sprawia, że podmioty zaangażowane $w$ funkcjonowanie technologii informacyjnej odgrywają główną rolę w społeczeństwie (Nauka ekstra, 2011, s. 16). Nasycenie informacją prowadzi do powstania: społeczeństwa opartego na nauce, racjonalności i refleksyjności; gospodarki, w której wszystkie wartości i sektory - nawet rolnictwo i przemysł - mają coraz większy związek z produkowaniem informacji; rynku pracy, na którym większość zawodów jest $w$ dużym stopniu lub całkowicie oparta na przetwarzaniu informacji, co wymaga odpowiedniej wiedzy i wyższego wykształcenia (stąd alternatywna nazwa społeczeństwa informacyjnego - społeczeństwo wiedzy); kultury zdominowanej przez produkty medialne i informacyjne z typowymi dla nich znakami, symbolami i znaczeniami (van Dijk, 2010). Manuel Castells społeczeństwo informacyjne definiuje jako specyficzną formę społecznej organizacji, w której wytwarzanie, przetwarzanie i transmisja informacji staje się fundamentalnym źródłem produktywności i władzy (van Dijk, 2010). Z kolei możliwość nieograniczonego korzystania z technologii teleinformatycznych powoduje wiele zagrożeń, a ich negatywne konsekwencje wpływają na funkcjonowanie sfery psychicznej i fizycznej jednostki, dlatego też społeczeństwo informacyjne można traktować również jako społeczeństwo ryzyka (Haber, Garwol, 2013).
} 
pojawiły się również nowe problemy związane z nierównym dostępem jednostek do wymienionych wcześniej elementów społeczeństwa informacyjnego i rozwój zjawiska zwanego wykluczeniem cyfrowym (Kluszczyński, 2001).

\section{Stan społeczeństwa informacyjnego w Polsce}

Poziom społeczeństwa informacyjnego w danym kraju można określać za pomocą pomiaru różnych czynników. Do najczęściej stosowanych w tym celu zalicza się dostępność technologii oraz stopień jej wykorzystania (Płoszaj, 2008). Niniejsze rozwiązanie zastosowano podczas realizacji projektu „ESPON 1.2.3 Społeczeństwo informacyjne”, w ramach którego skonstruowano regionalny wskaźnik społeczeństwa informacyjnego (SI) (Olechnicka \& Gorzelak, 2007, s. 50). Składowe wskaźnika są tożsame z fazami „cyklu życia” społeczeństwa informacyjnego i obejmują: 1) gotowość - zasoby i umiejętności niezbędne do rozwoju SI mierzone za pomocą następujących wskaźników: zasoby ludzkie w nauce i technice, gospodarstwa domowe wyposażone w telefon stacjonarny, odpowiedni dochód w gospodarstwach domowych, 2) wzrost - dostępność i wykorzystanie Information and Communication Technologies (ICT), wskaźniki: gospodarstwa domowe posiadające komputer osobisty, gospodarstwa domowe z przynajmniej jednym telefonem komórkowym, gospodarstwa domowe posiadające dostęp do Internetu, gospodarstwa domowe posiadające szerokopasmowy dostęp do Internetu, dostępność sieci światłowodowej, firmy z dostępem do Internetu, 3) oddziaływanie - wpływ na gospodarkę mierzony za pomocą wskaźników: zatrudnienie w sektorze wysokiej techniki, aplikacje patentowe w zakresie technologii informacyjnych i komunikacyjnych (Płoszaj, 2008). W niniejszym badaniu poziom SI w Polsce został oceniony jako bardzo niski. 15 na 16 polskich województw osiągnęło niższe stadium gotowości (najniższy stopień na skali), a poziom województwa mazowieckiego określono jako niski, wyrażający się w wyższym stadium gotowości. Zgodnie z powyższym Polskę zaliczono do europejskiej peryferii informacyjnej (Płoszaj, 2008). Warto nadmienić, że przywołane badanie zostało zrealizowane w 2007 r., od tego czasu poziom społeczeństwa informacyjnego uległ znacznej zmianie, a przytoczenie wyników projektu „ESPON 1.2.3 Społeczeństwo informacyjne” ma na celu uwidocznienie zmian zachodzących w polskim społeczeństwie w kwestii posiadania i korzystania z nowoczesnych technologii. Z najnowszych badań wynika, iż $72 \%$ gospodarstw domowych jest wyposażonych w komputery, a 71\% posiada dostęp do Internetu. Najliczniejszą grupę posiadających i korzystających, pod względem typów rodzin, stanowią małżeństwa z uczącymi się 
dziećmi. Aż 95\% z nich posiada komputer i dostęp do Internetu. Bardzo nieliczne są sytuacje, że w gospodarstwie domowym jest komputer, a nie ma dostępu do Internetu. Zdarzają się natomiast sytuacje odwrotne, tzn. dostęp do Internetu jest w tych domach, gdzie nie ma komputerów, ale są tablety i smartfony. Następuje bardzo duży przyrost liczby tabletów w ostatnich latach, pomiędzy 2013 a 2015 rokiem ich odsetek wzrósł z 9,2\% do 24,2\%, tj. aż o 15 punktów procentowych (Batorski, 2015).

Istotną zmianą, jaka zachodzi w zakresie dostępu do Internetu, jest wzrost przepustowości. Jak dotąd najpopularniejsze są łącza o przepustowości od 7 do 10Mb/s., jednakże bardzo szybko upowszechniają się łącza o dużo większej przepustowości. Europejska Agenda Cyfrowa wyznaczyła sobie ambitny cel osiągnięcia do 2020 r. następujących wyników: dostęp na poziomie $30 \mathrm{Mb} / \mathrm{s}$ dla wszystkich i przynajmniej $100 \mathrm{Mb} / \mathrm{s}$ dla połowy gospodarstw domowych. Wyniki Diagnozy Społecznej 2015 wskazują na regularny wzrost przepustowości dostępu do Internetu w Polsce. „Tempo podwajania się przepustowości jest mniej więcej stałe i w ostatnich kilkunastu latach przepustowość dostępu do Internetu w gospodarstwach domowych podwajała się co 19,4 miesiąca" (Batorski, 2015, s. 357).

\section{Wykluczenie cyfrowe - definicja, wymiary}

Początków powstawania koncepcji wykluczenia cyfrowego należy doszukiwać się w Stanach Zjednoczonych. Konsekwencją rosnącej popularności Internetu okazało się zróżnicowanie amerykańskiego społeczeństwa na information rich (informacyjnie bogatych) i information poor (informacyjnie biednych), bądź information haves (posiadających informacje) i information have-nots (nieposiadających informacji). W literaturze przedmiotu spotyka się również termin information and communication poverty (ubóstwo informacyjno-komunikacyjne). Potoczne i zarazem dosłowne znaczenie terminu digital divide oznacza podział cyfrowy, tj. przepaść pomiędzy posiadaczami dostępu do nowoczesnych technologii ICT oraz tymi, którzy tego dostępu nie posiadają. Jak wskazuje Łukasz Arendt jest to zbyt daleko idące uproszczenie, które generuje problemy natury etycznej i wyjaśnia omawiane zjawisko jedynie częściowo (Arendt, Kryńska, \& Kukulak-Dolata, 2011). Po pierwsze, może sugerować, iż jednostki posiadające dostęp do ICT w jakiejś mierze są lepsze od tych, które go nie posiadają. Po drugie, wyjaśnia zaledwie fragment problemu, gdyż traktuje wykluczenie cyfrowe w kategoriach zjawiska dualnego. Ponadto, powinno mówić się o wielu podziałach o charakterze społecznym, ekonomicznym i technologicznym. Należy również uwzględniać 
postawy, potrzeby, poglądy i indywidualne doświadczenia jednostek. Warto podkreślić, iż potoczne rozumienie digital divide wywodzi się z determinizmu technologicznego, zgodnie z którym wykluczenie cyfrowe jest efektem nierównomiernego rozprzestrzenia się technologii (Arendt i in., 2011).

W literaturze przedmiotu odnaleźć można inne sposoby definiowania omawianego zjawiska. Wykluczenie cyfrowe utożsamia się z systemowymi różnicami w dostępie i korzystaniu z nowoczesnych technologii pomiędzy jednostkami, które różnicuje wykształcenie, dochód, wykonywany zawód, miejsce zamieszkania oraz znajdującymi się na różnych etapach życia (Bujak, 2013). Jeszcze bardziej kompleksową definicję przedstawia Manuel Castells, dla którego wykluczenie cyfrowe to „podział przebiegający pomiędzy osobami, przedsiębiorstwami, instytucjami, regionami i społeczeństwami dysponującymi materialnymi i kulturowymi warunkami do funkcjonowania w cyfrowym świecie, a mimo to nie będącymi w stanie dostosować się do szybkiego tempa zachodzących zmian" (Castells, 2003, s. 270).

Mając na uwadze powyższe założenia teoretyczne, stwierdza się, iż pojęcie digital divide nie obejmuje całego spektrum zjawiska. Nie uwzględnia zakresu, w jakim technologie ICT są wykorzystywane przez użytkowników, pomija poziom kompetencji cyfrowych, istnienie niezbędnej infrastruktury oraz znaczenie czynników społecznych, ekonomicznych, organizacyjnych i kulturowych. W związku z powyższym, przyjmuje się, że bardziej adekwatnym określeniem wykluczenia cyfrowego jest termin digital exclusion.

W literaturze przedmiotu "wykluczenie cyfrowe" opisywane jest jako zjawisko wielowymiarowe. Pierwszy wymiar stanowi „wykluczenie motywacyjne”, które odnosi się do mentalnych barier i niechęci wobec nowych technologii, do których należą głównie: brak wiary we własne możliwości, brak motywacji i chęci do zapoznania się z nowoczesnymi technologiami oraz lęk przed nowościami (Zielińska, 2015). Drugi wymiar - materialny - związany jest z potocznym rozumieniem wykluczenia cyfrowego, tj. brakiem możliwości zakupu urządzeń, oprogramowania i usług dostępu do sieci. Trzeci wymiar dotyczy umiejętności i rozumiany jest jako brak możliwości zdobycia, utrzymania lub uaktualnienia zdolności związanych z obsługą ICT, a czwarty „wykorzystania”, które oznacza, że technologii używa się w określonym celu (Kryńska \& Arendt, 2010). Jak podkreśla Jan van Dijk powyższy model charakteryzuje się kumulacyjnością i rekursywnością (van Dijk, 2013). Poszczególne wymiary digital exclusion następują kolejno po sobie, a proces powtarza się w miarę pojawiania się nowych technologii. 


\section{Przyczyny występowania zjawiska digital exclusion}

Najogólniej można stwierdzić, iż samo społeczeństwo informacyjne stanowi główną przyczynę wykluczenia cyfrowego. W literaturze przedmiotu wyróżnia się dwa rodzaje przyczyn występowania wykluczenia cyfrowego (Wasiak, 2013). Do pierwszej grupy zalicza się czynniki zależne od człowieka, tj. jakość życia, dochód, umiejętności, cechy osobowości. Do drugiej grupy należą przyczyny niezależne od człowieka, czyli takie jak: hermetyczność wiedzy, wysoki stopień specjalizacji wiedzy, postęp technologiczny. W niniejszym artykule przyjmuje się, iż główne przyczyny wynikają z przedstawionych wcześniej wymiarów wykluczenia cyfrowego i należą do nich: brak motywacji, brak dostępu do technologii, niski poziom umiejętności cyfrowych oraz niski poziom wykorzystania ICT.

\section{Brak motywacji}

Brak motywacji do korzystania z nowoczesnych technologii może mieć następujące źródła. Po pierwsze, niektórzy nie posiadają odpowiedniej wiedzy, w jaki sposób korzystać ze sprzętu oraz jakie możliwości oferuje im sieć. Po drugie, oferta usług i treści prezentowanych w Internecie nie jest dostosowana do potrzeb i możliwości pewnych kategorii (np. osób niepełnosprawnych czy osób starszych). Po trzecie, istotną rolę odgrywa lęk ${ }^{2}$ (np. o bezpieczeństwo transakcji), a także błędne przekonania na temat skutków pracy przy komputerze (np. niebezpieczne promieniowanie) (Batorski \& Płoszaj, 2012). Jan van Dijk (2013), powołując się na niemieckie i amerykańskie badania, wskazuje na następujące powody odrzucenia technologii: brak potrzeby lub możliwości użytkowania, brak czasu lub chęci, traktowanie technologii jako niebezpiecznego medium, brak środków finansowych oraz brak odpowiednich kompetencji. Z danych GUS wynika, iż w 2014 r. aż 59,1\% osób, które nie miały dostępu do Internetu, po prostu nie odczuwały takiej potrzeby. Kolejną kategorię stanowiły jednostki, które nie posiadały ku temu odpowiednich umiejętności cyfrowych (44,9\%). Mimo spadających cen sprzętu oraz atrakcyjnych ofert operatorów 28,7\% Polaków uznało, iż koszt zakupu komputera był zbyt wysoki, a 22,4\% nie było stać na pokrywanie kosztów związanych z dostępem do Internetu. Niski wpływ na brak Internetu w gospodarstwie domowym wykazywały niechęć (5,7\%) czy niepełnosprawność (3,6\%) (Główny Urząd Statystyczny [GUS], 2014).

\footnotetext{
${ }^{2}$ Lęk przed technologiami rozumiany jest jako poczucie dyskomfortu, stresu lub strachu podczas styczności z nimi. Strach związany z użytkowaniem ICT potocznie nazywa się technofobią (van Dijk, 2013).
} 
Na przestrzeni kilku lat daje się zaobserwować niebezpieczne zjawisko związane z brakiem motywacji do korzystania z ICT. Otóż, wykształciła się nowa kategoria, do której należą jednostki posiadające w gospodarstwach domowych nowe technologie, a mimo to z nich nie korzystające. Odsetek osób, które posiadają w domu dostęp do Internetu, ale z niego nie korzystają powoli wzrasta. W 2007 r. wynosił niemal 11\%, natomiast w 2015 r. osiągnął wartość 15,4\%. Ponadto zdarza się, że osoby, które kiedyś korzystały z sieci, obecnie już tego nie robią. Pomiędzy 2013 a 2015 r., z Internetu zaczęło korzystać nieco ponad $5 \%$ osób w wieku 18+, ale równocześnie prawie 4\% przestało zaglądać do sieci. Ogólnie rzecz ujmując, do 2015 r. z Internetu przestało korzystać 6\% osób, które dwa lata wcześniej deklarowały się jako użytkownicy sieci (Batorski, 2015).

Sprzęt i szerokopasmowa sieć nie wystarczą do tego, by korzystanie z ICT było w Polsce rzeczywiście powszechne. Kluczowy jest jednak nie sam brak chęci korzystania, a raczej to, jakie są jego przyczyny, bo to one są podstawowymi barierami upowszechnienia technologii. Szczególnie istotną przeszkodę stanowi niski poziom wiedzy o ICT, który wpływa na pojawienie się innych negatywnych zjawisk: braku potrzeby korzystania, nieumiejętności użytkowania oraz problemów natury psychologicznej, w tym strachu oraz autowykluczenia ${ }^{3}$ (Batorski \& Płoszaj, 2012).

\section{Brak dostępu}

Od kilku lat wyniki kolejnych edycji badania Diagnoza społeczna wskazują na zmniejszanie się liczby gospodarstw domowych pozbawionych dostępu do nowoczesnych technologii. Najbardziej rozpowszechnioną w Polsce technologią jest telefon komórkowy. W 2003 r. „komórkę" posiadało 23\% użytkowników ICT, w 2011 r. - 85\%, a w 2015 r. już 90,5\% badanych. Pomiędzy 2003 a 2015 r. odsetek gospodarstw domowych wyposażonych w komputer wzrósł o 36,1 p. proc. Obecnie następuje wypieranie komputerów stacjonarnych przez komputery przenośne. W 2013 r. różnica jeszcze nie była zbyt duża; 49,3\% gospodarstw domowych posiadało laptopy, natomiast 46,9\% komputery stacjonarne. Już w 2015 r. laptopy były obecne w 59\% domów, podczas gdy komputery stacjonarne posiadało 40\% gospodarstw domowych (Batorski, 2015). Z danych CBOS wynika, że internauci obecnie

\footnotetext{
${ }^{3}$ Autowykluczenie dotyczy przejawiania deklaracji typu „to nie dla mnie”, związane jest również z poczuciem niechęci wobec zmian i nowości, a kształcenie ustawiczne traktuje jako zbędne (Batorski \& Płoszaj, 2012).
} 
stanowią niemal dwie trzecie mieszkańców Polski. Niemal wszyscy użytkownicy posiadają połączenie $z$ Internetem $w$ domach, ale wraz z rosnącą popularnością urządzeń mobilnych, coraz więcej zwolenników zyskuje bezprzewodowe łączenie się z siecią (Feliksiak, 2015). Korzystanie z Internetu jest mocno powiązane z posiadaniem telefonu komórkowego. Użytkownikami sieci jest aż 93\% posiadaczy smartfonów, 52\% posiadaczy zwykłego aparatu i zaledwie $8 \%$ osób, które nie mają telefonu (Batorski, 2015). Na posiadanie komputerów i dostępu do Internetu istotny wpływ ma obecność dzieci. W 2014 r. komputery były obecne w $68,2 \%$ gospodarstw "bez dzieci” i w 94,8\% gospodarstw „z dziećmi", a Internet analogicznie w 65,2\% i 94\% gospodarstw (GUS, 2014).

W Polsce zauważa się regionalne zróżnicowanie w dostępie do technologii ICT. Na tle kraju wyróżnia się województwo pomorskie, w którym 85,4\% gospodarstw domowych posiada komputery i 78,8\% dostęp do szerokopasmowego Internetu. Aż w dziewięciu województwach odsetek posiadaczy komputerów jest niższy niż średnia wartość dla kraju, tj. 77,1\%. Do województw o najniższym odsetku dostępu do szerokopasmowego Internetu należą: lubuskie (63,3\%), warmińsko-mazurskie (64,1\%), tódzkie (66\%), zachodniopomorskie (66,5\%) i śląskie (68,2\%) (GUS, 2014).

Zaledwie 13,3\% badanych w 2011 r. nie korzystało z żadnej z nowych technologii. Natomiast 55\% Polaków korzystało zarówno z "komórki", jak i z komputera i Internetu. Odsetek korzystających „z 3 technologii” pomiędzy 2005 a 2011 r. wzrósł o 28,4 p. proc. Zmniejsza się natomiast odsetek gospodarstw wyposażonych w telefon stacjonarny (Batorski, 2011).

\section{Niski poziom umiejętności cyfrowych}

Pod pojęciem „kompetencje cyfrowe” kryje się szereg umiejętności związanych z używaniem nowoczesnych technologii. Kompetencje cyfrowe można podzielić na dwa rodzaje: medialne i merytoryczne. W ramach kompetencji medialnych wyróżnia się następujące umiejętności: operacyjne (działania niezbędne do obsługi, np. komputera) i formalne (poszukiwanie i nawigacja). Do kompetencji merytorycznych należą natomiast umiejętności: informacyjne (wyszukiwanie, selekcjonowanie, ocenianie informacji), komunikacyjne (obsługa poczty, kontaktowanie się, tworzenie profilu on-line, wydawanie opinii), strategiczne (traktowanie technologii jako środka służącego do realizacji celów osobistych i zawodowych), twórcze (redagowanie treści wg własnych upodobań) (van Dijk, 2013). 
Ogólnie można stwierdzić, iż Polacy charakteryzują się posiadaniem zaledwie podstawowych umiejętności cyfrowych polegających na: używaniu wyszukiwarki internetowej $(91,5 \%)$, kopiowaniu/przenoszeniu pliku/folderu (69,7\%), stosowaniu poleceń kopiuj/ wytnij/wklej (63,2\%). Aż 63,9\% użytkowników komputerów nie potrafi wykonać podstawowych poleceń w arkuszu kalkulacyjnym, a 76,8\% nie przygotuje prezentacji elektronicznej (Batorski, 2011). W 2014 r. umiejętność korzystania z podstawowych funkcji matematycznych w arkuszu kalkulacyjnym zadeklarowało 52,2\% osób w wieku 12-15 lat oraz 49,5\% osób pomiędzy 16 a 74 r.ż, natomiast wykonanie prezentacji multimedialnej odpowiednio 41,7\% (12-15 lat) i 29,7\% (16-74 lata) (GUS, 2014). W 2011 roku specjalistyczne umiejętności polegające na napisaniu programu komputerowego z użyciem języka programowania znane były zaledwie 8,8\% użytkowników (Batorski, 2011), natomiast w 2014 r. umiejętność ta była znana 7,2\% osób w wieku 12-15 lat oraz 7,6\% osób w wieku 16-74 lata (GUS, 2014). Czynności wykonywane w Internecie sprowadzają się głównie do rozwijania umiejętności komunikacyjnych poprzez wysyłanie e-maili z załącznikami (72,7\%), branie udziału w czatach, forach dyskusyjnych (40,5\%), telefonowaniu za pomocą Internetu $(44,5 \%)^{4}(G U S, 2014)$.

Niestety niski poziom umiejętności cyfrowych związany jest z wiekiem. Badanie z 2012 r., jakie przeprowadzono w związku z testowaniem aplikacji „Go-myLife" ${ }^{\prime 5}$ potwierdza istnienie trudności z korzystaniem z nowoczesnych technologii wśród osób powyżej 60 r.ż. Seniorzy wskazywali następujące niedogodności i problemy: brak instrukcji korzystania z aplikacji w wersji tradycyjnej (papierowej), trudność z zapamiętywaniem co oznaczają poszczególne przyciski i ikony, konieczność posiadania hasła i loginu, zbyt mały rozmiar czcionki, zbyt małe wyświetlacze smartfonów, problemy techniczne związane z dostępem i korzystaniem z platformy, a także problemy ze zrozumieniem języka nowych technologii (Zielińska, 2015).

\section{Niski poziom wykorzystania technologii ICT}

Poziom wykorzystania możliwości, jakie dają nowoczesne technologie, w głównej mierze wynika $z$ wiedzy i kompetencji. Niski poziom umiejętności cyfrowych implikuje mało efektywne sposoby korzystania z komputera, Internetu i innych technologii typu smartfon czy telewizor smartTv.

\footnotetext{
${ }^{4}$ Przedstawione dane dotyczą badanych w wieku 17-74 lata.

5 "Go-myLife” jest to aplikacja dla seniorów, której głównym celem jest „umożliwienie i ułatwienie interakcji z innymi osobami, jak również poprawienie dostępu do informacji, co ostatecznie - zgodnie z założeniami projektu - przełoży się na poprawę jakości życia seniorów, dzięki korzystaniu z platformy społecznościowej i mobilnych nowych technologii: smartfonów, tabletów, laptopów i innych urządzeń" (Zielińska, 2015).
} 
Zasadniczym celem korzystania z komputera okazuje się być praca (33,8\%). Dla niemal co piątego użytkownika komputer służy do nauki, a co czwarty jako główny cel korzystania z komputera wskazał rozrywkę (Batorski, 2007\%). Internetu używa się głównie do korzystania z poczty elektronicznej (82\%), wyszukiwania informacji o towarach i usługach (73,6\%). Dla niemal połowy badanych Internet służy do korzystania z usług bankowych, robienia zakupów, szukania informacji dotyczących zdrowia, pobierania i czytania czasopism, a także słuchania radia. Co czwarty internauta wybiera e-administrację w celu poszukiwania informacji na stronach urzędowych. Zaledwie 8,7\% użytkowników korzysta z tzw. przestrzeni cyfrowej ze względu na możliwość: korzystania z plików na różnych urządzeniach i w różnych miejscach, łatwego udostępniania plików znajomym oraz ze względów bezpieczeństwa. Smartfon służy jako urządzenie do obsługi poczty elektronicznej, sprawdzania prognozy pogody czy korzystania z kalendarza dla kilkunastu procent użytkowników. Telewizor typu SmartTv w stopniu podstawowym7 obsługuje 14\% badanych (GUS, 2014).

\section{Zagrożeni wykluczeniem cyfrowym}

Dotychczasowe badania wskazują na korzystny związek pomiędzy wykorzystywaniem nowoczesnych technik przepływu informacji a rozwojem gospodarczym i poziomem życia Polaków (Bujak, 2013). Z drugiej strony coraz bardziej widoczne stają się dysproporcje pomiędzy „informacyjnie bogatymi” i „informacyjnie biednymi”. Ponadto dynamiczne zmiany związane z użytkowaniem technologii dotyczą głównie tempa, a nie zakresu przemian. Dlatego zastosowanie znajduje tutaj charakterystyczne dla procesów globalizacyjnych powiedzenie, zgodnie z którym „bogaci się bogacą, a biedni biednieją”. Na gruncie technologicznym oznacza to, że pewna grupa osób korzystających z technologii systematycznie inwestuje w sprzęt i usługi informatyczne mając świadomość ich zalet i wymiernych korzyści, jakie może przynieść sięganie po nie. Natomiast osoby, które z różnych przyczyn nie korzystały z wysokich technologii, stawiają inne potrzeby na pierwszym miejscu, odsuwając zakup komputera, interfejsu, uzyskanie dostępu do Internetu na nieokreśloną przyszłość. W konsekwencji szybszy rozwój życia społecznego będzie nadal prowadził do marginalizacji części środowisk, które z powodu braku dostępu do nowoczesnych technologii czy nieumiejętności ich obsługi nie będą miały możliwości dogonienia świata, który ucieka (Bujak, 2013).

\footnotetext{
${ }^{6}$ Przywołano dane z 2007 r., ponieważ nowsze wyniki badań odnoszą się do umiejętności korzystania z komputera (np. kopiowanie, przenoszenie folderu), a tutaj chodzi o powody korzystania.

${ }^{7}$ Dotyczy usług oferowanych przez daną stację telewizyjną.
} 
Za Magdaleną Szpunar przyjąć należy, iż do „wykluczonych cyfrowo” zalicza się jednostki o niskim statusie materialnym, z pewnym typem upośledzenia, tj. głuchoniemych, niedowidzących, z dysfunkcją kończyn, a także - przejawiające lęk wobec nowości i nierozumiejące założeń społeczeństwa informacyjnego (Szpunar, 2005).

Zmienną w największym stopniu determinującą korzystanie z Internetu jest wiek. $Z$ sieci niemal powszechnie korzystają młodzi badani, w wieku od 18 do 34 lat oraz znaczna większość osób w wieku 35-44 lata. Wśród użytkowników od 45 do 54 lat internauci stanowią ponad połowę, natomiast wśród osób starszych (55-64 lata) zaledwie dwie piąte, a wśród najstarszych, tj. powyżej 65 r.ż. tylko jedną szóstą (Feliksiak, 2015). Ponadto badacze alarmują, iż nie ma przesłanek, aby sytuacja uległa zmianie. Wciąż szybszy przyrost użytkowników Internetu następuje wśród osób młodych. Istotne znaczenie ma również wykształcenie. W 2015 roku z sieci korzystały prawie wszystkie osoby legitymujące się wykształceniem gimnazjalnym (94\%) ${ }^{8}$ i taki sam odsetek osób z wykształceniem wyższym (94\%) Zaledwie 18\% internautów posiada wykształcenie podstawowe (Feliksiak, 2015). Wśród niekorzystających takich osób jest ponad 33,4\%, a z wykształceniem zasadniczym zawodowym 39,4\% (Batorski, 2015). Badania dowodzą, że im mniejsza miejscowość zamieszkania, tym większe prawdopodobieństwo bycia „wykluczonym cyfrowo”. W 2015 r. 43\% mieszkańców wsi, 34\% mieszkańców miast poniżej 20 tys., 33\% mieszkańców miast do 100 tys., 27\% mieszkańców miast do 200 tys., 24\% mieszkańców miast do 500 tys. oraz 17,6\% mieszkańców największych miast, tj. powyżej 500 tys. osób nadal nie było użytkownikami Internetu. Korzystanie z nowoczesnych technologii różnicuje również poziom zamożności. Wcześniej zaczynają korzystać osoby lepiej sytuowane, ale zależność ta nie jest tak istotna jak w przypadku wieku czy wykształcenia. Wśród Polaków o najniższych dochodach nieco ponad połowa w 2015 r. korzystała z sieci (Batorski, 2015). Analizując najnowsze wyniki badań mało aktualne wydaje się być stwierdzenie Benjamina Barbera (2005, s. 428), zgodnie z którym „kiedy pierwszoplanowym celem stanie się opłacalność, innowacje techniczne będą raczej utrwalać istniejące nierówności, a niskie dochody będą ograniczać dostęp do informacji". Co ciekawe, na zasobność w nowoczesne technologie wpływa również wielkość gospodarstwa domowego. Jak wspomniano na początku artykułu, posiadanie komputera i Internetu jest domeną małżeństw z dziećmi, a kategorią zagrożoną wykluczeniem cyfrowym są głównie osoby mieszkające samotnie, w szczególności osoby starsze.

\footnotetext{
${ }^{8}$ Ze względu na to, że są to osoby w trakcie procesu uczenia się; uczniowie szkół średnich (ponadgimnazjalnych).
} 


\section{Społeczne konsekwencje}

Niewątpliwie, wykluczenie cyfrowe - jako nowy rodzaj wykluczenia społecznego XXI w. jest zjawiskiem, którego konsekwencje dostrzega się w wielu dziedzinach życia. Jednostki wykluczone cyfrowo są skazane na gorszą pozycję na rynku europejskim jako:

- pracownicy ${ }^{9}$, ponieważ brak umiejętności cyfrowych prowadzi do obniżenia ich konkurencyjności;

- konsumenci, gdyż brak dostępu do informacji skutkuje ponoszeniem większych wydatków, brakiem samodzielności;

- obywatele, poprzez brak dostępu do usług publicznych oferowanych w sieci (Wasiak, 2013).

Z badań wynika, iż jednostki bierne wobec Internetu wykazują niższy poziom kapitału społecznego ze względu na nieutrzymywanie kontaktów online. Ponadto aktywność w sieci implikuje wyższą aktywność w życiu społecznym i kulturalnym. Aż 72\% korzystających i zaledwie 36\% niekorzystających z ICT uczestniczy w spotkaniach towarzyskich. „Wykluczeni cyfrowo" przejawiają niższą frekwencję wyborczą, co świadczy o niższym poziomie świadomości i partycypacji obywatelskiej. Najwięcej zagrożeń dostrzega się jednak w sferze pracy. Otóż, niekorzystający z ICT mają mniejsze szanse na znalezienie pracy bądź zmianę lub awans w dotychczasowej, ze względu na brak motywacji i umiejętności podnoszenia kwalifikacji zawodowych (Batorski \& Płoszaj, 2012). Niewątpliwie, najpoważniejszą konsekwencją wykluczenia cyfrowego jest fakt, iż staje się ono przyczyną bycia „wykluczonym społecznie". Dlatego tak istotną kwestię stanowi kompleksowe przeciwdziałanie zjawisku, w szczególności w obszarach największego ryzyka.

\section{Przeciwdziałanie wykluczeniu cyfrowemu na obszarach wiejskich}

Wobec szybko rozwijającej się informatyzacji wszystkich dziedzin życia oraz złożoności zjawiska wykluczenia cyfrowego dużym wyzwaniem dla administracji rządowej, samorządów i organizacji społecznych jest włączenie grup zagrożonych wykluczeniem do grona osób korzystających w pełni z możliwości, jakie daje Internet poprzez likwidację barier, zarówno

\footnotetext{
9 "W grupie 25-40 lat odsetek pracujących jest wśród internautów o około 20 pkt. proc. wyższy niż wśród osób niekorzystających" (Batorski \& Płoszaj, 2012, s. 25).
} 
technologicznych, jak i psychologicznych. Przy czym wydaje się, iż decydująca jest tu rola państwa, które powinno informować, inspirować i wspomagać inne podmioty, takie jak jednostki samorządowe czy organizacje społeczne (Stawicka, 2015).

Przykładem działań, jakie realizowały jednostki samorządu terytorialnego, było zapewnienie dostępu do Internetu oraz niezbędnych szkoleń osobom zagrożonym wykluczeniem cyfrowym, współfinansowane ze środków Europejskiego Funduszu Rozwoju Regionalnego w ramach Programu Operacyjnego Innowacyjna Gospodarka 2007-2013: działanie 8.3 „Przeciwdziałanie wykluczeniu cyfrowemu - elnclusion”, oś priorytetowa 8. „Społeczeństwo informacyjne - zwiększenie innowacyjności gospodarki” (Stawicka, 2015).

Poniżej, jako ilustrację, przedstawiono przykłady projektów mających na celu przeciwdziałanie digital exclusion, które realizowano w gminach wiejskich powiatu skierniewickiego ${ }^{10}$. Zgodnie z podziałem administracyjnym powiat należy do województwa łódzkiego, a w jego skład wchodzi dziewięć gmin: Bolimów, Maków, Lipce Reymontowskie, Godzianów, Słupia, Głuchów, Kowiesy, Nowy Kawęczyn, Skierniewice. Powiat skierniewicki o powierzchni 755,11 $\mathrm{km}^{2}$ zajmuje 13 miejsce wśród powiatów województwa łódzkiego. Dziewięć gmin powiatu ziemskiego obejmuje powierzchnię $756 \mathrm{~km}^{2}$. Niniejszy obszar zamieszkuje 38600 mieszkańców".

Z Europejskiego Funduszu Rozwoju Regionalnego (EFRR) w ramach Programu Operacyjnego Innowacyjna Gospodarka, działanie 8.3. „Przeciwdziałanie wykluczeniu cyfrowemu - e-Inclusion”, zrealizowano następujące projekty: Internet dla mieszkańców gminy Bolimów - przeciwdziałanie wykluczeniu cyfrowemu, Eliminacja wykluczenia cyfrowego w gminie Kowiesy, Przeciwdziałanie wykluczeniu cyfrowemu - e-Inclusion w gminie Maków, Łagodzenie skutków wykluczenia cyfrowego w gminie Słupia na łączną wartość 6490 639,75 zł. Projekty głównie zostały skierowane do osób, które zamieszkiwały na obszarze danej gminy, nie posiadały sprzętu i dostępu do Internetu, a ponadto znajdowały się w trudnej sytuacji materialnej ${ }^{12}$. Beneficjentami projektów były również: osoby ze znacznym lub umiarkowanym stopniem niepełnosprawności, dzieci i młodzież z bardzo dobrymi wynikami w nauce, osoby z grupy 50+, osoby samotnie wychowujące dzieci oraz rodziny zastępcze. Oferowane wsparcie, wynikające z ogólnego celu projektów, polegało na przekazaniu sprzętu z oprogramowaniem i zapewnieniu dostępu do szerokopasmowego

\footnotetext{
${ }^{10}$ Teren powiatu skierniewickiego wybrano ze względu na miejsce zamieszkania autorki artykułu.

11 Źródło danych: „Plan rozwoju lokalnego powiatu skierniewickiego" (b.d.).

12 Dotyczy zarówno mieszkańców, jak i gospodarstw domowych.
} 
Internetu. Beneficjenci uczestniczyli również w szkoleniach z zakresu obsługi komputera i użytkowania Internetu. Gminy ponadto przekazały komputery z dostępem do Internetu instytucjom podległym, tj. szkołom, GOPS-om, bibliotekom. Łącznie wsparcie uzyskało 21 tego typu instytucji.

W powiecie zrealizowano następujące projekty w ramach Regionalnego Programu Operacyjnego Województwa Łódzkiego na lata 2007-2013, oś priorytetowa IV Społeczeństwo Informacyjne, działanie IV.2 E- usługi publiczne: Szkoła przyszłości - e-kształcenie szansą na rozwój Gminy Głuchów i E-kształcenie zmienia uczniów, uczniowie zmieniają Gminę Skierniewice. Łączna wartość projektów wyniosła 819 057,00 zł. Projekty zostały skierowane do szkół podstawowych i gimnazjów z terenu gmin. Głównym celem projektów było wyrównanie dysproporcji w dostępie i wykorzystaniu technologii ICT oraz podniesienie poziomu korzystania z ICT. Udzielone wsparcie obejmowało: zakup 390. tabletów z systemem operacyjnym i dysków sieciowych umożliwiających archiwizację dokumentów, utworzenie sieci Wi-Fi oraz przeprowadzenie szkoleń dotyczących optymalnego wykorzystania technologii w procesie e-kształcenia.

Podsumowując, należy stwierdzić, iż realizacja projektów przeciwdziałających digital exclusion staje się coraz bardziej popularna na obszarach wiejskich. Z roku na rok przybywa gmin, które pozyskują środki na niniejszy cel. Niewątpliwie, istotną rolę odgrywają środki oferowane w ramach pomocy unijnej.

\section{PO PC szansą na lata 2014-2020}

PO Polska Cyfrowa 2014-2020 jest kolejnym po PO Innowacyjna Gospodarka programem operacyjnym, w ramach którego można wnioskować o środki na realizację projektów przeciwdziałających lub niwelujących skutki wykluczenia cyfrowego. Program został przyjęty przez Radę Ministrów 8 stycznia 2014 r. i zatwierdzony przez Komisję Europejską 5 grudnia 2014 r. Autorzy programu - Ministerstwo Administracji i Cyfryzacji oraz Ministerstwo Infrastruktury i Rozwoju - deklarują ścisłą współpracę z partnerami z różnych obszarów czyli organizacjami pozarządowymi, samorządami i inwestorami (Stawicka, 2015).

Do głównych celów PO PC zalicza się: budowę, rozbudowę lub przebudowę sieci zapewniających szybki (powyżej $30 \mathrm{MB} / \mathrm{s}$ ) szerokopasmowy dostęp do Internetu, tworzenie przyjaznej obywatelom e-administracji, otwieranie zasobów publicznych oraz zwiększanie kompetencji cyfrowych osób zagrożonych wykluczeniem cyfrowym. Przewiduje się realizację działań 
PO PC w ramach trzech przedmiotowych osi priorytetowych: oś priorytetowa I - Powszechny dostęp do szybkiego Internetu, oś priorytetowa II - E-administracja i otwarty rząd, oś priorytetowa III - Cyfrowa aktywizacja społeczeństwa. Dodatkowo przygotowano oś priorytetową IV - Pomoc techniczna. Projekty realizowane w ramach PO PC kierowane są do jednostek administracji rządowej oraz jednostek im podległych, jednostek naukowych, państwowych organizacji kultury, organizacji pozarządowych i przedsiębiorstw. Łączna wartość środków do wydatkowania wynosi ok. 2 mld euro, z czego $880 \mathrm{mln}$ euro zostanie przeznaczone na budowę sieci szerokopasmowego Internetu i e-administrację $e^{13}$.

PO PC jest komplementarny z dokumentami strategicznymi na poziomie UE, m.in. ze Strategią Europy 2020, Europejską Agendą Cyfrową, i na poziomie kraju, m.in. ze Strategią Rozwoju Kraju 2020, Strategią Sprawne Państwo, a w szczególności z jej dokumentami wykonawczymi Programem Zintegrowanej Informatyzacji Państwa oraz Narodowym Planem Szerokopasmowym (Hołubowicz, 2013).

\section{Podsumowanie}

Jak wynika z przedstawionych badań, główną przyczyną ograniczonego rozwoju społeczeństwa informacyjnego i tym samym istnienia kategorii „wykluczonych cyfrowo” jest przede wszystkim niski poziom umiejętności cyfrowych, mało efektywne korzystanie z nowoczesnych technologii, a także brak motywacji, rzadziej brak dostępu. Istotne jest angażowanie podmiotów lokalnych (samorządów, przedsiębiorców, organizacji pozarządowych) we wspólne inicjatywy oraz promowanie działań o charakterze edukacyjnym w celu podnoszenia poziomu umiejętności korzystania.

\section{Bibliografia}

Aftański, P. (2011). Społeczeństwo informacyjne - nowy wymiar informacji. W C. Hales \& B. Mikuła (Red.), Społeczeństwo informacyjne: Gospodarka, technologie, procesy (s. 67-69.). Kraków: Wyd. UE.

Arendt, Ł., Kryńska, E., \& Kukulak-Dolata, I. (2011). Przeciwdziałanie wykluczeniu cyfrowemu na Mazowszu. Warszawa: IPiSS.

Barber, B. (2005). Dżihad kontra McŚwiat. Warszawa: WWL Muza S. A.

${ }^{13}$ Źródło danych: „Polska Cyfrowa” (b.d.). 
Batorski, D. (2007). Uwarunkowania i konsekwencje z korzystania technologii informacyjno-komunikacyjnych. W J. Czapiński \& T. Panek (Red.), Diagnoza społeczna 2007: Warunki i jakość życia Polaków (ss. 268-288). Warszawa: Rada Monitoringu Społecznego.

Batorski, D. (2011). Korzystanie z technologii komunikacyjno-informacyjnych. W J. Czapiński \& T. Panek (Red.), Diagnoza społeczna 2011: Warunki i jakość życia Polaków (ss. 299-327). Warszawa: Rada Monitoringu Społecznego.

Batorski, D. (2015). Technologie i media w domach i w życiu Polaków. W J. Czapiński \& T. Panek (Red.), Diagnoza społeczna 2015: Warunki i jakość życia Polaków (ss. 373-395). Warszawa: Rada Monitoringu Społecznego.

Batorski, D., \& Płoszaj, A. (2012). Diagnoza i rekomendacje w obszarze kompetencji cyfrowych społeczeństwa i przeciwdziałania wykluczeniu cyfrowemu w kontekście zaprogramowania wsparcia w latach 2014-2020. Warszawa: Ministerstwo Rozwoju Regionalnego.

Bujak, A. (2013). Wykluczenie cyfrowe jako szczególny przykład wykluczenia społecznego w gospodarce opartej na wiedzy. W M. Pokrzywa \& S. Wilk (Red.), Wykluczenie społeczne: Diagnoza, wymiary i kierunki badań (ss. 263-275). Rzeszów: Wyd. URz.

Castells, M. (2003). Galaktyka Internetu: Refleksja nad Internetem, biznesem i społeczeństwem (T. Hornowski, Tłum.). Poznań: Rebis.

van Dijk, J. (2010). Społeczne aspekty nowych mediów (J. Konieczny, Tłum.). Warszawa: PWN. van Dijk, J. (2013). Ewolucja wykluczenia cyfrowego: Od dostępu po kompetencje i użytkowanie (M. Zielińska-Choina, Tłum.). W M. Pokrzywa \& S. Wilk (Red.), Wykluczenie społeczne: Diagnoza, wymiary i kierunki badań (ss. 207-232). Rzeszów: Wyd. URz.

Feliksiak, M. (2015). Internauci 2015: Komunikat z badań. Warszawa: CBOS.

Haber, L. H., \& Garwol, K. (2013). Technologie teleinformatyczne jako źródła patologii w społeczeństwie informacyjnym. W M. Pokrzywa \& S. Wilk (Red.), Wykluczenie społeczne: Diagnoza, wymiary i kierunki badań (ss. 54-56). Rzeszów: Wyd. URz.

Hołubowicz, W. (2013). Raport z ewaluacji ex-ante Programu Operacyjnego dotyczącego rozwoju cyfrowego. Poznań: ITTI.

Kluszczyński, R. (2001). Społeczeństwo informacyjne. Cyberkultura. Sztuka multimediów. Kraków: Rabid.

Kryńska, E., \& Arendt, Ł. (2010). Wykluczenie cyfrowe na rynku pracy. Warszawa: IPiSS.

Muszyński, J. (2010). Społeczeństwo informacyjne - przewodnik - leksykon. Warszawa: PWN.

Nauka ekstra: T. 19. Społeczeństwo informacyjne. (2011). Warszawa: Biblioteka Gazety Wyborczej. Nauka, technika, innowacje i społeczeństwo informacyjne w Polsce. (2014). Warszawa: GUS.

Olechnicka, A., \& Gorzelak, G. (2007). Społeczeństwo informacyjne w przestrzeni Europy. Studia Regionalne i Lokalne, 2007(1(27)), 50.

Plan rozwoju lokalnego powiatu skierniewickiego. (b.d.). Pobrano 15 czerwca 2014, z http:// powiat-skierniewice.pl/pliki_aktualnosci/PlanRozwojuLokalnegoPowiatu Skierniewickiego 2007-2013.pdf 
Płoszaj, A. (2008). Polska cyfrowo podzielona. IT w Administracji, 2008(11).

Polska Cyfrowa. (b.d.). Pobrano 12 kwietnia 2015, z http://programoperacyjny.pl/programy_ unijne/polska_cyfrowa/

Stawicka, A. (2015). Wykluczenie cyfrowe w Polsce. Warszawa: Kancelaria Senatu. Biuro Analiz i Dokumentacji.

Szpunar, M. (2005). Cyfrowy podział - nowa forma stratyfikacji społecznych. W J. Kleban \& W. Wieczerzycki (Red.), Era społeczeństwa informacyjnego: Wyzwania, szanse, zagrożenia: Materiały konferencyjne (ss. 102-103). Poznań: Wyd. WsKiZ.

Wasiak, M. (2013). Gospodarka oparta na wiedzy a wykluczenie cyfrowe: Analiza porównawcza nowych krajów członkowskich UE. W M. Pokrzywa \& S. Wilk (Red.), Wykluczenie społeczne: Diagnoza, wymiary i kierunki badań (ss. 277-295). Rzeszów: Wyd. URz.

Zielińska, I. (2015). Seniorzy w wirtualnym świecie - możliwości i bariery: Na podstawie testów aplikacji Go-myLife. W A. Leszczyńska-Rejcher, L. Domańska, \& E. Subocz (Red.), Seniorzy w pryzmacie koncepcji „Społeczeństwo dla wszystkich grup wiekowych". Olsztyn: Wyd. UW-M.

\section{Digital exclusion: definitions, causes, countermeasures}

\section{Abstract}

The purpose of this article is to present some forms of digital exclusion. The article discusses what digital exclusion is and identifies the main causes and social consequences of the phenomenon. By determining the ways of counteracting digital exclusion, the author refers to Operational Programme Digital Poland for 2014-2020. In addition, the author presents the results of her analysis of preventing digital exclusion in rural areas.

\section{Keywords:}

digital exclusion, ICT, access, digital skills

\section{Digital exclusion - definicje, przyczyny, przeciwdziałanie}

\section{Abstrakt}

Celem niniejszego artykułu jest przedstawienie zjawiska wykluczenia cyfrowego. W artykule omówiono, czym jest wykluczenie cyfrowe, wskazano główne przyczyny oraz społeczne konsekwencje zjawiska. Określając sposoby przeciwdziałania wykluczeniu cyfrowemu, autorka odwołuje się do Programu Operacyjnego Polska Cyfrowa. Ponadto autorka przedstawia 
wyniki wykonanej przez siebie analizy dotyczącej przeciwdziałania wykluczeniu cyfrowemu na obszarach wiejskich.

\section{Słowa kluczowe:}

wykluczenie cyfrowe, technologie informacyjno-komunikacyjne, dostęp, umiejętności cyfrowe

\section{Citation:}

Tomczyńska, W. (2017). Digital exclusion - definicje, przyczyny, przeciwdziałanie. Adeptus, 2017(10). https://doi.org/10.11649/a.1503 